\title{
OPENINGS IN MATHEMATICS
}

\section{UNIVERSTTY OF SASKATCHEWAN}

Applications are invited for the position of head of a new Department of Computational Science at the Saskatoon Campus. Duties will involve organization of the department including the development of courses and the recruiting of staff.

The academic rank of the appointe will depend upon qualifications and experience but it is not expected the rank will be below that of an Associate Professor. Present salary scales are:

(1) Associate Professor - $\$ 11,500$ - $\$ 14,600$

(2) Professor - $\$ 15,000$ with no maximum.

Applications and enquiries should be sent to the Vice-Presidert (Administration), University of Saskatchewan, Saskatoon, Saskatchewan.

\section{UNIVERSITE DE SHERBROOKE}

Plusieurs postes sont actuellement vacants au sein du département de mathématiques. Salaries et rang selon l'expérience. (Salaire de base pour docteur en mathématiques et sans expérience: $\$ 8,100$.) Les mathématiciens spécialisés en algèbre, analyse fonctionnelle, statistiques, analyse numérique, etc..., sont particulièrement recherchés. 
